\title{
Effect of Fertilizers Application through Fertigation System on Chili Cultivation on Tin Mined Land in Bangka Island
}

\author{
IGM. Subiksa ${ }^{*}$, M. Oka Adnyana ${ }^{2}$, Umi Haryati ${ }^{1}$, Husnain ${ }^{1}$ \\ ${ }^{1}$ Indonesian Soil Research Institute \\ ${ }^{2}$ Center for Food Crop Research and Development
}

*Corresponding Author: IGM. Subiksa, Indonesian Soil Research Institute

\begin{abstract}
Tin mined land characterized by sandy texture, high hydraulic conductivity, low nutrient holding capacity and low nutrient status. Therefore, fertilizer use efficiency maybe very low and most of nutrient applied will be lost through leaching. Some efforts to increase nutrients availability and fertilizers use efficiency should be done so that crop productivity can beeconomically increased. Research on effect of fertilizers application through fertigation system on chili cultivation was carried out on tin mined land in Bukit Kijang Village Bangka Island. The objectives of research were: (1) to examine effect of fertilization through irrigation network to the growth and yield of chili; and (2) to improve the efficiency use of fertilizers application for chili cultivation on tin mined land. Research is carried out in a factorial randomized block design with 4 replications, where the $1^{\text {st }}$ factor is kind of ameliorant namely: manure and mixture of manure and bio-char. Meanwhile the $2^{\text {nd }}$ factor is the application methods and type of fertilizer namely side-band compound NPK 16-16-16 (F0), fertigation with commercial AB-mix fertilizer (F1) and fertigation with $A A R D$ 's AB-mix fertilizer (F2). Research resultsrevealed thatsandy tailinghas $84 \%$ sand fraction, low CEC and low nutrient status. Soil bulk density (BD) values ranged from 1.32 to $1.47 \mathrm{~g} \mathrm{~cm}^{-3}$ and total pores space (TPS) varies from 44.7 - 48.4\% v/v, wheremostly dominated by fast drainage pores (FDP) ranges from 22.3 to $30.1 \% \mathrm{v} / \mathrm{v}$. The application of manure+biochar ameliorant showed better plant growth compared to just manure ameliorant. It was alsoshowed by two parameters observed namely: plant height and stem diameter. The mixture of manure+biochar was also affected thetotal number of harvested chili fruit and total chili yield from 16 consecutive harvests. It was due tobio-char has higher pH compare to manure. Type of fertilizers and application methods have significantly affectedthegrowth and yield of chili on tin mined land. With conventional fertilization using NPK 16-16-16, total chili yield from 16 consecutive harvests is about 2,527 $\mathrm{kg} / \mathrm{ha}$. The commercial AB-mix increased fresh chili yield atabout $115 \%$ compared to conventional NPK treatment orbecome 5,436 kg/ha. Meanwhile, the AARD developed AB-mix also increased fresh chili yield about twice (100\%) compared to conventional NPK orbecome 5,067 kg/ha. There is no significant different between commercial $A B$-mix and AARD developed AB-mix, but chili yield of commercial AB-mix little bit higher than AARD AB-mix. It revealed that the effectiveness of both AB-mix fertilizers formula is almost same.
\end{abstract}

Keywords: tin mined land, sandy tailing, fertigation, ameliorant, AB-mix, chili, efficiency

\section{INTRODUCTION}

Tin mined land widely spread out in Bangka Belitung provinces (Babel), the largest tin producer in Indonesia. In Bangka Island itself, most of area in the mainland is belong to Tin Mine Concession of PT. Timah and PT. Kobatin (Bappeda Bangka 2000), as a result, the impacts of mining operation have affected the environment safety such as soil quality and various aspects of community life. The open pit mining operation left the huge area become sandy tailing, piles of subsoil and excavated pond named kolong (Latifah, 2000). Provincial Government Development Planning (Bappeda) of Bangka Belitung Province (2007) reported that there are at least 991 excavated ponds with total area about 4,638 ha. Tin mining activities also caused loss of biodiversity of natural flora and fauna, cessation of soil microbiology activities and declining of land quality and productivity (Adewole and Adesina, 2011). According to Setiadi (1997), one of the causes of declining environmental quality is high heavy metal content of tailings. Unsuitable tailing will exacerbate situations that lead to severe land degradation. 
Biotechnology Research Center for Forest and Environment IPB (2002) revealed that soil sample taken from sandy tailing in Central Bangka Regency has very high content of sand fraction (88-96\%). Sand content $>85 \%$ is also reported by Santi (2005) and Hanura (2005) in several other places. The soil with the dominant sand fraction causes the soil unable to keep soil moisture, easily dries and increasing soil temperature very high at noon. Rain water as a natural source of water will leach out quickly through infiltration and evaporation processes. As a result the plants will experience drought stress and even in the worst condition it will be dead. Reduced land cover also potential to change local microclimate conditions. High local air temperature causes the plants grown in extreme environmental stress. Mitchell (1959) in Ang et al., (1999) suggested that maximum land surface temperature in sandy tailings can reach $48.8^{\circ} \mathrm{C}$. Tanpibal and Sahunalu (1989) also reported that surface temperatures of sandy tailings ranged from $40-50^{\circ} \mathrm{C}$.

The physical characteristic of tin tailing dominated by sand fractions which is directly affected the chemical soil properties. Cations exchange capacity (CEC) in sandy tailings is only about 4.35 cmol.kg ${ }^{-1}$ (Santi 2005) and $2.27 \mathrm{cmolkg}^{-1}$ (Hanura 2005) while in humic tailings is about $6.99 \mathrm{cmolkg}^{-}$ ${ }^{1}$. The very low CEC, $0.95-1.15 \mathrm{cmolkg}^{-1}$ was also reported by IPB's Biotechnology Research Center for Forest and Environment (2002). The macro nutrient content such as N, P, and K in sandy tailing and humic tailing are in range low to very low. N-total content ranged from 0.03-0.17\%, P-Bray 4.20$10.65 \mu \mathrm{g} \mathrm{g}^{-1}$, K-exch $0.00-0.32 \mathrm{cmolkg}^{-1}$. Subardja et al., (2012) concluded that very low nutrient content and bases cations were used to tin tailings texture dominated by sand fractions. The same condition was also reported by Santi (2005) and Hanura (2005) in other place of Bangka Island, by Awang (1988) in tin tailings in Malaysia Peninsulaland by Tanpibal and Sahunalu (1989) in Thailand.

Due to the such soil physical and chemical conditions, the fertility status of tin mined land is generally very low, in contrary some elements such as $\mathrm{Fe}$ and $\mathrm{Al}$ were potentially become toxic element to the plants. Puslittanak (1996) showed that some efforts to improve the sandy tin mined land is not enough if only applying organic material, but must be also added the mineral soil that has at least $30 \%$ clay content in order to promote interaction of clay and organic matter. All those treatments will be increased water holding capacity which is a most challenge in the management of mined land. Asmarhansyah et al. (2012) suggested that improvement of the soil physical properties could be done by applying cow dung manure about $20 \mathrm{t} / \mathrm{ha}$. It is also significantly improves the soil chemical properties.

Based on fact of soil physic and chemical properties, therefore, tin mined land should be reclaimed to be more productive land, so that can be utilized by surrounding community. The multi-dimensional efforts should be done to reclaime tin mined land and to improve their productivity. Water supply must be provided continuously due to their low water holding capacity.Therefore, to reduce the frequency of water application without any effect to the plant could be done by improve soil water holding capacity (Chanthai and Wonprasaid, 2016). Drip irrigation is one of the special efforts to improve water use efficiency on sandy soil. On the other hand, the ability of soil to hold water should be enhanced by applying hydrophilic materials. Incorporating coir dust at $2 \%$ of the soil weight was able to increase soil water holding capacity by $40 \%$ (Chanthai and Wonprasaid, 2016). Manure and hydrogel are another examples that can be apply toincrease water holding capacity and reduce the rate of water loss. Many studies results indicated that applying ameliorants can also improve chemical properties especially nutrient status and CEC.

Hot chili (Capsicum frutescens) is the most valuable crop at some regions of Indonesia. However, chili cultivation on tin mined land needs many efforts due to severe land degradation. Applying fertilizers on sandy tailing for chili cultivation must be done frequently with low rate to avoid nutrient leaching. Fertilization through drip irrigation (called fertigation) is expected to increase the effectiveness and efficiency use of fertilizers. Nesthad et al. (2013) stated that growth and yield of chili using fertigation methods was affected by different irrigation level and different drip system layout. Mods et al. (2015) suggested that cost to produce $1 \mathrm{~kg}$ chili using fertigation technique was lower compare to conventional cultivation. Research on the effect of applying fertilizer through fertigation to support the productivity of horticultural crops on tin mined land was carried out at Bangka Island. This research is a special effort to solve the problems that was faced by the farmer for years in that kind of sandy texture soil. The objectives of this research are: (1) to examine the effect of fertilization through fertigation system for chili crop on tin mined land; and (2) to improve the efficiency of fertilizers use for chili cultivation on tin mined land. 


\section{MATERIAL AND MethodS}

\subsection{Material}

Materials required are consist of chemicals for the AB-mix fertilizer formula, cow dung manure and bio-char for ameliorant, NPK fertilizer, materials for drip irrigation equipment network and other supporting materials. Manure used was cow dung compost taken from livestock around the study area. Bio-char was made from rice husk taken from rice mill around the study site. The homogenous mixture of manure and biochar made in 1:1 v/v ratio. Ameliorant was given at the planting hole about $1 \mathrm{~kg}$ per hole1 week before planting. Conventional solid fertilizer NPK 16-16-16 with total dose 800 $\mathrm{kg} \mathrm{ha}^{-1}$, given as basal fertilizer as much as $30 \%$ total dose, and the rest $70 \%$ split into 4 time side band application every two weeks starting from 1 month after planting. Meanwhile the AB-mix liquid fertilizer which is applied 2 times a week during 4 months. The AB-mix fertilizer in form of dilute solution applied twice a week and each application needs about $0.25-0.40 \mathrm{~L}$ per plant. In case of soil moisture become low, water supply needed and it was done by drip irrigation with frequency 2 times a week or as needed based on soil moisture condition.

\subsection{Methods}

\subsubsection{Plot Design}

The hot chili (capsicum frutecens) as crop indicator planted on $10 \mathrm{~m}$ long and $1.0 \mathrm{~m}$ wide bed with 60 $\mathrm{cm}$ x $50 \mathrm{~cm}$ planting distance. Each treatment consists of 2 adjoining beds and before planted in the beds, chili seed was sowed in the nursery for 3 weeks. The research was carried out on the tin mined land in Bukit Kijang Village, Central Bangka Regency, Bangka Belitung Province. The study was conducted from August 2016 to March 2017.

The study used a factorial randomized block design with 4 replications. The $1^{\text {st }}$ factor waskind of ameliorant and $2^{\text {nd }}$ factor was the application methods and type of fertilizer. There were two kinds of ameliorant tested namely manure compost $24 \mathrm{t} \mathrm{ha}^{-1}$ (A1) and mixture of manure+biochar24 t ha ${ }^{-1}$ (A2). Meanwhile type of fertilizers and application methods tested were conventional NPK 16-16-16 side band applied or farmer's common practice (F0), commercial $\mathrm{AB}$-mix fertilizers applied through fertigation system (F1) and AARD developed AB-mix fertilizer applied through fertigation system (F2). An irrigation network consist of box water storage, electric pump, water tank, distribution HDPE pipe network, water filter, and driper. Water tank position was $1 \mathrm{~m}$ above soil surface, so that water can flow with gravity force.

\subsubsection{Data Collection}

Composit soil sample before treatment was taken after land leveling done for physical and chemical soil analysis. Soil sample consist of composite soil sample for chemical properties analysis and undisturbed soil sample taken using ring sampler for physical soil properties. Soil samples after season taken from each treatment and 4 replication. Observations were made on several parameters consist of: physical and chemical properties of soil, plant height, stems diameter and fresh chili yield. Data on cost structure were also collected that consisted of fix cost, inputs cost, labor cost, and other cost.

\subsubsection{Financial Feasibility Analysis}

Financial analysis is exercised to analyze the financial feasibility of chili cultivation at an area of about 1 hectare. This analysis comparing between common practice by farmer namely using conventional solid NPK fertilizer with side band application and fertigation system using AB-mix fertilizer applied through irrigation network. Both of conventional NPK and fertigation system assumed using mixture of manure+biochar ameliorant. Average on-farm chilli yield (ton/ha) was corrected with $10 \%$ correction factor from attained chili yield in $30 \mathrm{~m} 2$ planting bed.Then, fresh chili yield is used as the main output with respect to agricultural inputs used per hectare. R/C ratio is exercised to analyze the financial feasibility of chili cultivation with recorded cost component that include fixed cost and variable cost (Swastika 2004). The following formulas are used to analyze onfarm income and its financial feasibility (Muhammad et al. 2012 and Marimin 2014).

NI $\quad=$ TR - TC

$\mathrm{TR} \quad=\mathrm{P} * \mathrm{Q}$ 


$$
\begin{array}{ll}
\mathrm{TC} & =\mathrm{TFC}+\mathrm{TVC} \\
\mathrm{R} / \mathrm{C} & =\mathrm{TR} / \mathrm{TC} \text { or } \\
\mathrm{B} / \mathrm{C} & =\mathrm{NI} / \mathrm{TC}
\end{array}
$$

Where

$$
\begin{array}{ll}
\mathrm{NI} & =\text { Net On-farm Income (USD/ha) } \\
\mathrm{TR} & =\text { Total Revenue (USD/ha) } \\
\mathrm{TC} & =\text { Total Cost (USD/ha) } \\
\mathrm{P} & =\text { Yield Price }(\mathrm{USD} / \mathrm{ton}) \\
\mathrm{Q} & =\text { Yield (ton/ha) } \\
\mathrm{TFC} & =\text { Total Fixed Cost (USD/ha) } \\
\mathrm{TVC} & =\text { Total Variable Cost (USD/ha) }
\end{array}
$$

If $\mathrm{R} / \mathrm{C}>1.0$ or $\mathrm{B} / \mathrm{C}>0.0$ then fertigation base chilli farming technology demonstrated applied in this research is financially feasible that can be developed in situ or outreaching to other similar land areas. On the other hand, if $\mathrm{R} / \mathrm{C}<1.0$ or $\mathrm{B} / \mathrm{C}<0.0$, this indicated that this technology is not feasible to be developed further. On the other hand, in order to measure the additional benefit that gained by new technology with respect to the farmer practices, MBCR (marginal benefit cost ratio) then exercised as follow:

MBCR $=\frac{\text { Total Gains }}{\text { Total Losses }}$

Total Gains $=$ Total additional income gained from introduced technology

Total Losses $\quad=$ Total additional cost expended due to application of introduced technology.

If MBCR > 1, the introduced technology is financially feasible to be scaling up in situ or out reaching to newly open area. Otherwise, if MBCR $\leq 1$ then chilli cultivation technology did not feasible or the introduced technology just the same with farmer practices or even worst.

\section{RESULTS AND DISCUSSION}

\subsection{Soil Characteristics}

The existing condition of tin mined land in Bukit Kijang Village which is classified as sandy tailing, physically very different compared to the original condition. Sandy tailing dominated by silica sand (white color) spread out at most of surround research site and there are many ponds scattered on that area. The result of soil sample analysis taken compositely in the study site showed that soil is belong to sand texture, acid and low in organic matter content (Table 1). Nutrients content especially P and $\mathrm{K}$ are also very low status as a result of low clay content. Exchangeable bases consist of $\mathrm{Ca}, \mathrm{Mg}, \mathrm{K}$ and $\mathrm{Na}$ are also very low due to very low negative soil charges (CEC), capability of soil to hold cations, then cations will be experienced leaching. Soil charges dominated by exchangeable $\mathrm{Ca}$, but still belong in low status category. Due to low organic matter and low CEC, soil will be very easy loss their moisture content and crop potentially experienced water stress. The others impact faced is fertilizer use efficiency should be very low due to low CEC. Most of nutrient will be loss through leaching, if fertilizer applied in excess capacity. It is concluded that research site has low fertility status and low fertilizer use efficiency. Therefore, some efforts should be done to increase soil productivity and optimum plant growth.

Table1. Chemical characteristics of composite soil sample taken from Bukit Kijang

\begin{tabular}{|c|c|c|c|}
\hline No. & Parameters & Value & Remarks \\
\hline 1. & Texsture : & 84 & Sand \\
& Sand & 13 & \\
Silt & 3 & Very low \\
& $\mathrm{Clay}$ & 5.7 & \\
\hline 2. & $\mathrm{pH}:$ & 4.9 & Very low \\
& $\mathrm{H}$ O & 0.21 & Very low \\
& $\mathrm{KCl}$ & 0.03 & Very low \\
\hline
\end{tabular}


Effect of Fertilizers Application through Fertigation System on Chili Cultivation on Tin Mined Land in Bangka Island

\begin{tabular}{|c|c|c|c|}
\hline 4. & $\begin{array}{c}\text { Extractable } \mathrm{HCl} 25 \%: \\
\mathrm{P}_{2} \mathrm{O}_{5}\left(\mathrm{mg} 100 \mathrm{~g}^{-1}\right) \\
\mathrm{K}_{2} \mathrm{O}\left(\mathrm{mg} 100 \mathrm{~g}^{-1}\right)\end{array}$ & $\begin{array}{c}14 \\
3\end{array}$ & $\begin{array}{l}\text { Very low } \\
\text { Very low }\end{array}$ \\
\hline 5. & P2O5 (Bray-1) & 21 & Very low \\
\hline 6. & $\begin{array}{c}\text { Exchangeable cations: } \\
\mathrm{Ca}\left(\mathrm{cmol} \mathrm{kg}^{-1}\right) \\
\mathrm{Mg}\left(\mathrm{cmol} \mathrm{kg}^{-1}\right) \\
\mathrm{K}\left(\mathrm{cmol} \mathrm{kg}^{-1}\right) \\
\mathrm{Na}\left(\mathrm{cmol} \mathrm{kg}^{-1}\right) \\
\text { Total }\left(\mathrm{cmol} \mathrm{kg}^{-1}\right)\end{array}$ & $\begin{array}{l}0.29 \\
0.12 \\
0.05 \\
0.02 \\
0.48\end{array}$ & $\begin{array}{l}\text { Very low } \\
\text { Very low } \\
\text { Very low } \\
\text { Very low } \\
\text { Very low }\end{array}$ \\
\hline 7. & $\mathrm{CEC}\left(\mathrm{cmol} \mathrm{kg}^{-1}\right)$ & 2,19 & Very low \\
\hline 8. & $\mathrm{Al}, \mathrm{KCl} 1 \mathrm{~N}\left(\mathrm{cmol} \mathrm{kg}^{-1}\right)$ & 0 & Very low \\
\hline 9. & $\mathrm{H}, \mathrm{KCl} 1 \mathrm{~N}\left(\mathrm{cmol} \mathrm{kg}^{-1}\right)$ & 0.10 & Very low \\
\hline 10. & Base saturation $(\%)$ & 22 & low \\
\hline 11. & Al saturation $(\%)$ & 0 & Very low \\
\hline
\end{tabular}

Result of physical soil analysis showed that all physical properties parameters were not change significantly before and after planting season (Table 2). Bulk density (BD) values before treament was about $1.4 \mathrm{~g} \mathrm{~cm}^{-3}$, and after harvest, BD ranged from 1.32 to $1.37 \mathrm{~g} \mathrm{~cm}^{-3}$. Particle density (PD) before treatment was about $2.5 \mathrm{~g} \mathrm{~cm}^{-3}$ and after harvest PD range from $2.50-2.66 \mathrm{~g} \mathrm{~cm}^{-3}$. A total pore space (TPS) initially at $46.2 \mathrm{v} / \mathrm{v}$ then becomes varies from $44.7 \mathrm{v} / \mathrm{v}$ to $48.4 \% \mathrm{v} / \mathrm{v}$. Soil moisture content in certain condition $(\mathrm{pF})$ showed little bit higher after harvest due to manure and biochar treatment. It's mean incorporating of soil with manure and biochar could increase water holding capacity. Fast drainage pores (FDP), slow drainage pores (SDP) and water available pores (WAP) were no significantly different before and after season. It was concluded that soil in the experimental site has a poor physical properties to support optimum plant growth. The soil has high BD and PD, so that soil tends to be dense and will inhibit the penetration of plant roots to deeper soil layers.

Table2. Change in soil physical properties by treatment

\begin{tabular}{|c|c|c|c|c|c|c|c|c|c|c|}
\hline \multirow{2}{*}{$\begin{array}{l}\text { Physical } \\
\text { properties }\end{array}$} & \multirow{2}{*}{ Unit } & \multirow{2}{*}{ Origin } & \multicolumn{6}{|c|}{ Treatment plots } & \multirow{2}{*}{ Mean } & \multirow{2}{*}{ Category } \\
\hline & & & A1 F0 & A1 F1 & A1 F2 & A2 F0 & A2 F1 & A2 F2 & & \\
\hline Soil moisture & $\% \mathrm{w} / \mathrm{w}$ & 26.9 & 14,8 & 15,2 & 14,3 & 14,7 & 12,2 & 14,6 & 14,3 & Very low \\
\hline $\begin{array}{l}\text { Bulk Density } \\
\text { (BD) }\end{array}$ & $\mathrm{g} \mathrm{cm}^{-3}$ & 1.4 & 1,36 & 1,32 & 1,37 & 1,37 & 1,36 & 1,34 & 1,37 & High \\
\hline $\begin{array}{c}\text { Particle Density } \\
\text { (PD) }\end{array}$ & $\mathrm{g} \mathrm{cm}^{-3}$ & 2.5 & 2,50 & 2,54 & 2,66 & 2,58 & 2,61 & 2,59 & 2,58 & High \\
\hline TPS & $\% \mathrm{v} / \mathrm{v}$ & 46.2 & 45,2 & 48,1 & 44,7 & 47,0 & 47,9 & 48,4 & 46,9 & Medium \\
\hline \multicolumn{11}{|l|}{$\begin{array}{l}\text { Moisture } \\
\text { content in } \\
\text { certain } \\
\text { condition: }\end{array}$} \\
\hline $\mathrm{pF}-1$ & $\% \mathrm{v} / \mathrm{v}$ & 37,2 & 37,6 & 38,3 & 43,0 & 38,8 & 40,7 & 42,9 & 39,9 & Low \\
\hline $\mathrm{pF}-2$ & $\% \mathrm{v} / \mathrm{v}$ & 16,7 & 17,6 & 18,6 & 22,5 & 18,7 & 18,8 & 18,6 & 19,0 & Low \\
\hline $\mathrm{pF}-2.54$ & $\% \mathrm{v} / \mathrm{v}$ & 12,0 & 13,5 & 13,2 & 13.7 & 14,2 & 17.4 & 14,1 & 14,2 & Low \\
\hline $\mathrm{pF} 4.2$ & $\% \mathrm{v} / \mathrm{v}$ & 2,8 & 3,9 & 5,7 & 6,3 & 4,7 & 4,4 & 4,6 & 4,9 & Low \\
\hline FDP & $\% \mathrm{v} / \mathrm{v}$ & 29,5 & 27,6 & 29,5 & 22,3 & 28,3 & 30,1 & 29,8 & 27,9 & High \\
\hline SDP & $\% \mathrm{v} / \mathrm{v}$ & 4,7 & 5,1 & 5,4 & 5,1 & 4,5 & 4,1 & 4,5 & 4,8 & Very low \\
\hline WAP & $\% \mathrm{v} / \mathrm{v}$ & 9,3 & 8,6 & 7,5 & 11,1 & 9,5 & 9,3 & 9,5 & 9,3 & Low \\
\hline
\end{tabular}

Noted: $A 1=$ manure $24 \mathrm{t} / \mathrm{ha}, A 2=$ manure+biochar $(1: 1 \mathrm{v} / \mathrm{v}) 24 \mathrm{t} / \mathrm{ha}, F 0=N P K$ 16-16-16 side band, Fl= commercial $A B$-mix fertigation, $F 2=A A R D$ developed $A B$-mix fertigation; TPS=total pore space; SDP=slow drainage pores; $W A P=$ water available pores; $p F-1=$ saturated condition; $p F-2.54=$ field capacity condition; $p F-4.2=$ wilting point condition; $w / w=$ weight/weight $; / v=$ volume/volume.

Incorporating manure and biochar to the soil tends to decrease soil BD. This condition will affect to the plant roots development and explored deeper soil layer. The soil also has lowTPS and SDP conversely high in FDP. That's mean the soil has a low water holding capacity (WHC) so that soil moisture will loss very fast. Incorporating manure and biochar tends to increase water holding 
Effect of Fertilizers Application through Fertigation System on Chili Cultivation on Tin Mined Land in Bangka Island

capacity, so that irrigation was more eficient and risk of plant water stress decreased. Among parameters observed, only water holding capacity showed significant different due to manure and biochar treatment (Table 3).

Table3. Change in soil chemical properties by treatment

\begin{tabular}{|c|c|c|c|c|c|c|c|c|}
\hline \multirow{2}{*}{ Chemical properties } & \multirow{2}{*}{ Unit } & \multirow{2}{*}{ Origin } & \multicolumn{6}{|c|}{ Treatment plots } \\
\hline & & & A1 F0 & A1 F1 & A1 F2 & A2 F0 & A2 F1 & A2 F2 \\
\hline Soil pH & & 5.7 & 5.9 & 5.8 & 5.9 & 6.1 & 6.0 & 6.2 \\
\hline Org-C & $\%$ & 0.21 & 0.68 & 0.60 & 0.75 & 0,81 & 0.92 & 0.87 \\
\hline Total N & $\%$ & 0.03 & 0.06 & 0.06 & 0.09 & 0.08 & 0.08 & 0.07 \\
\hline $\mathrm{P}_{2} \mathrm{O}_{5}$ & mg. $100 \mathrm{~g}-1$ & 14 & 49.9 & 76.12 & 61.72 & 60.35 & 98.11 & 52.94 \\
\hline $\mathrm{K}_{2} \mathrm{O}$ & mg. $100 \mathrm{~g}-1$ & 3 & 4.06 & 6.33 & 3.71 & 5,42 & 7.14 & 5.03 \\
\hline $\mathrm{Ca}$ & cmol. $\mathrm{kg}^{-1}$ & 0.29 & 1.74 & 1.89 & 1.68 & 1.62 & 1.84 & 1.78 \\
\hline $\mathrm{Mg}$ & cmol. $\mathrm{kg}^{-1}$ & 0.12 & 0.53 & 0.54 & 0.50 & 0.52 & 0.48 & 0.51 \\
\hline CEC & cmol. $\mathrm{kg}^{-1}$ & 1,38 & 2.78 & 3.02 & 2.66 & 2.81 & 2.97 & 7.13 \\
\hline $\mathrm{BS}$ & $\%$ & 22 & 83.25 & 86.81 & 84.06 & 71.97 & 84.68 & 55.44 \\
\hline
\end{tabular}

Noted: $A 1=$ manure $24 \mathrm{t} / \mathrm{ha}, A 2=$ manure+biochar $(1: 1 \mathrm{v} / \mathrm{v}) 24 \mathrm{t} / \mathrm{ha}, F 0=N P K$ 16-16-16 side band, Fl= commercial $A B$-mix fertigation, $F 2=A A R D$ developed $A B$-mix fertigation; $T P S=$ total pore space; $S D P=$ slow drainage pores; $W A P=$ water available pores; $p F-1=$ saturated condition; $p F-2.54=$ field capacity condition; $p F-4.2=$ wilting point condition $; w / w=$ weight/weight $; / v=$ volume/volume.

\subsection{Plant Height}

The average of chili plant height by treatment showed in Table 4 and Table 5. Plant height data showed that type of ameliorant has a significantly effect to plant growth. The mixture of manure and biochar (A2) showed better chili growth compared to just manure ameliorant (A1). This is likely related to the effect of biochar which has alkaline in nature so that it has good impact to improve soil acidity. The $\mathrm{pH}$ improvement within plant root zone will be resulting better root development and better plant growth. Conversely, manure from cow dung application tends to give an acid effect because of manure contain organic acid.

The type of fertilizer formula has significantly effect to the plant height in early stage of vegetative growth, especially if mixture of manure and biochar applied. Chili plant height observed significantly higher than NPK treatment. However, there was no significantly different after 60 DAP. The conventional NPK 16-16-16 (F0) fertilizer treatment showed no significant different plant height compare toboth of commercial AB-mix formula (F1) and AARD AB-mix formula after 60 DAP. This showed that the determinants of the growth of chili plants in tin mined land are how to improve soil in the root zone. It is concluded that vegetative growth of chili is not depend on type of fertilizer and methods of application.

Table4. Chili plant height by treatment of ameliorant and type of fertilizer applied at 30 DAP

\begin{tabular}{|c|c|c|c|}
\hline \multirow{2}{*}{ Treatment } & \multicolumn{3}{|c|}{ Plant Height at 30 DAP* $(\mathrm{cm})$} \\
\cline { 2 - 4 } & Manure & Manure+Biochar & Average \\
\hline NPK & $52,33 \mathrm{a}$ & $54,53 \mathrm{a}$ & 53.43 \\
\hline Commercial AB-mix & $53,65 \mathrm{a}$ & $60,90 \mathrm{~b}$ & 57.28 \\
\hline AARD AB-mix & $56,00 \mathrm{a}$ & $57,35 \mathrm{ab}$ & 56.68 \\
\hline Average & $\mathbf{5 3 . 9 9} \mathbf{A}$ & $\mathbf{5 7 . 5 9} \mathbf{B}$ & \\
\hline
\end{tabular}

*) DAP = day after planting; Number in same coloum followed by same letter showed no significantly different by $5 \%$ DMRT

Table5. Chili plant height by treatment of ameliorant and type of fertilizer applied at $60 \mathrm{DAP}$

\begin{tabular}{|c|c|c|c|}
\hline \multirow{2}{*}{ Treatment } & \multicolumn{3}{|c|}{ Plant Height at 60 DAP $(\mathrm{cm})$} \\
\cline { 2 - 4 } & Manure & Manure+Biochar & Average \\
\hline NPK & $74,38 \mathbf{a}$ & $83,80 \mathbf{a}$ & 79.09 \\
\hline Commercial AB-mix & $77,83 \mathbf{a}$ & $88,10 \mathbf{a}$ & 82.97 \\
\hline AARD AB-mix & $75,58 \mathbf{a}$ & $84,90 \mathbf{a}$ & \\
\hline Average & $\mathbf{7 5 . 9 3} \mathbf{A}$ & $\mathbf{8 5 . 6 0} \mathbf{~ B}$ & \\
\hline
\end{tabular}

*) DAP = day after planting; Number in same coloum followed by same letter showed no significantly different by $5 \%$ DMRT 


\subsection{Stem Diameter}

The average of chili plant stem diameter data, measured $10 \mathrm{~cm}$ from the soil surface showed in Table 6 and Table 7. The stem diameter of chili is one indicator of plant health because large and solid stems reflected root development in the soil. The results showed that mixture of manure + biochar ameliorant consistently had a larger stem diameter than the only manure of cow dung compost ameliorant. This is an indication that plant roots are healthier if manure + biochar applied. It is maybe because of higher soil $\mathrm{pH}$ at root zone due to lime effect of biochar, so that it becomes more conducive for root development. Meanwhile, kind of fertilizer formula and application method did not show any clear differences or pattern between conventional fertilizer NPK (F0), commercial AB-mix (F1) and AARD AB-mix (F2) formula at 30 DAP. This suggested that complete nutrition in the ABmix formula has no effect on plant vegetative growth. This is likely due to macro nutrient NPK is still as dominant factor in vegetative growth. The stem diameter exceed than $1 \mathrm{~cm}$ at 60DAP indicates the chili growth is optimally develop. The significant effect of commercial AB-mix observed at 60 DAP where stem diameter significantly larger than NPK treatment if manure and biochar applied.

Table6. Plant stem diameter by treatment of ameliorant and type of fertilizer applied at 30 DAP

\begin{tabular}{|c|c|c|c|}
\hline \multirow{2}{*}{ Treatment } & \multicolumn{3}{|c|}{ Stem Diameter at 30 DAP ${ }^{*}(\mathrm{~cm})$} \\
\cline { 2 - 4 } & Manure & Manure+Biochar & Average \\
\hline NPK & $0,77 \mathrm{a}$ & $0,80 \mathrm{a}$ & 0.79 \\
\hline Commercial AB-mix & $0,79 \mathrm{a}$ & $0,83 \mathrm{a}$ & 0.81 \\
\hline AARD AB-mix & $0,78 \mathrm{a}$ & $0,80 \mathrm{a}$ & 0.79 \\
\hline Average & $\mathbf{0 . 7 8} \mathbf{A}$ & $\mathbf{0 . 8 1} \mathbf{A}$ & \\
\hline
\end{tabular}

*) DAP = day after planting; Number in same coloum followed by same letter showed no significantly different by $5 \%$ DMRT

Table7. Plant stem diameter by treatment of ameliorant and type of fertilizer applied at 60 DAP

\begin{tabular}{|c|c|c|c|}
\hline \multirow{2}{*}{ Treatment } & \multicolumn{3}{|c|}{ Stem Diameter at 60 DAP ${ }^{*}(\mathrm{~cm})$} \\
\cline { 2 - 4 } & Manure & Manure+Biochar & Average \\
\hline NPK & $1,11 \mathrm{a}$ & $1,11 \mathrm{a}$ & 1.11 \\
\hline Commercial AB-mix & $1,12 \mathrm{a}$ & $1,23 \mathrm{~b}$ & 1.18 \\
\hline AARD AB-mix & $1,09 \mathrm{a}$ & $1,17 \mathrm{ab}$ & 1.13 \\
\hline Average & $\mathbf{1 . 1 1} \mathbf{A}$ & $\mathbf{1 . 1 7} \mathbf{B}$ & \\
\hline
\end{tabular}

*) DAP = day after planting; Number in same coloum followed by same letter showed no significantly different by $5 \%$ DMRT

\subsection{Crop Yield}

Chili fruit harvested when the fruit color changes from white to red. Harvesting have done in the sample plot within the whole treatment plot. The average of fresh chili fruits yield shown in Table 8 . Chili fruits development started after 60 DAP almost in all plots. The results showed that plants treated with mixture of manure + biochar consistently has more number of fruits compare to just manure treatment. As a result, fresh chili yield significantly increased about $28 \%$ if tin mined land treated with mixture of manure+biochar ameliorant compared to manure ameliorant. With manure ameliorant treatment, the average of total fresh chili yield from 16 consecutive harvest is about 11.43 $\mathrm{kg} / 30 \mathrm{~m}^{2}(3,811 \mathrm{~kg} / \mathrm{ha}$. Meanwhile with mixture of manure+biochar treatment, total yield from 16 consecutive harvest is about $14.62 \mathrm{~kg} / 30 \mathrm{~m} 2(4,875 \mathrm{~kg} / \mathrm{ha})$. This result showed that biochar plays an important role on the quality of ameliorant. Biochar has an alkaline effect to reduce soil acidity at the root zone.Anonim (2018) stated that biochar can increase soil fertility of acid soils (low pH soils), increase land productivity, and provide protection against some foliar and soil-borne diseases.

Table8. Total fresh chili yield from 16 consecutive harvest inplanting bed $30 \quad m^{2}$ by treatment of ameliorant and type of fertilizer.

\begin{tabular}{|c|c|c|c|}
\hline \multirow{2}{*}{ Treatment } & \multicolumn{3}{|c|}{ Fresh Chili Yield (kg) } \\
\cline { 2 - 4 } & Manure & Manure+Biochar & Average \\
\hline NPK (Conventional) & $6.87 \mathrm{a}$ & $8.28 \mathrm{a}$ & $\mathbf{7 . 5 8} \mathbf{A}$ \\
\hline Commercial AB-mix & $13.59 \mathrm{~b}$ & $19.03 \mathrm{~b}$ & $\mathbf{1 6 . 3 1 ~ B}$ \\
\hline AARD AB-mix & $13.84 \mathrm{~b}$ & $16.56 \mathrm{~b}$ & $\mathbf{1 5 . 2 0} \mathbf{B}$ \\
\hline Average & $\mathbf{1 1 . 4 3 ~ A}$ & $\mathbf{1 4 . 6 2} \mathbf{B}$ & \\
\hline
\end{tabular}

Number in same coloum followed by same letter showed no significantly different by 5\% DMRT

International Journal of Research Studies in Agricultural Sciences (IJRSAS) 
The AB-mix fertilizer, both of commercial and AARD formula, have significantly effect and consistent to the number of harvested chili fruits compare to conventional NPK fertilization. Common farmer practice using solid conventional NPK attained fresh chili yield $7.58 \mathrm{~kg} / 30 \mathrm{~m} 2(2,527 \mathrm{~kg} / \mathrm{ha})$ in average. Using Commercial AB-mix attained yield increased $115 \%$ become $16.31 \mathrm{~kg} / 30 \mathrm{~m} 2(5,436$ $\mathrm{kg} / \mathrm{ha}$ ). This increase is due tothe AB-mix fertilizer has complete nutrient content both macro and micro nutrients, while conventional NPK content is only macro nutrients N, P and K. As mention before, tin mined land has low macro and micro nutrient status, so that all nutrient needed for optimum growth should be provided through fertilization. The micro nutrient such as $\mathrm{Cu}, \mathrm{Zn}$ and $\mathrm{B}$ play an important role in generative growth which includes the formation of flowers and fruits. This finding in line with Chanthai and Wonprasaid (2016) that Fertigation improved all plant growth and yield components compared to soil application. Its effect on plant growth and yield was attributed to greater nutrient uptake and fertilizer use efficiency.

An increase of the number chili fruits followed by an increase of fresh chili yield. With conventional solid NPK treatment, the total fresh chili yield from 16 consecutive harvests is about $8.28 \mathrm{~kg} / 30$ $\mathrm{m}^{2}$ planting bed $(2,760 \mathrm{~kg} / \mathrm{ha})$ (Table 8$)$. The commercial AB-mix increased fresh chili yield about $130 \%$ compare to conventional NPK treatment become $19.03 \mathrm{~kg} / 30 \mathrm{~m}^{2}(6,345 \mathrm{~kg} / \mathrm{ha})$. Meanwhile, AARD AB-mix increased fresh chili fruit about twice (100\%) also compare to conventional NPK become $16.56 \mathrm{~kg} / 30 \mathrm{~m}^{2}$ planting bed $(5,520 \mathrm{~kg} / \mathrm{ha})$. There is no significant differences between commercial AB-mix and AARD AB-mix, but chili yield of commercial AB-mix little bit higher than AARD AB-mix, but statistically no significant different. It revealed that both of AB-mix formula has the same effect to yield (Tabel 8).

Figure 1 showed comparison of fresh chili attained yield between manure and mixture of manure+biochar ameliorant treatment. Fresh chili yield started from $6^{\text {th }}$ harvest, attained yield with treatment of manure+biochar was higher compared to attained yield with just manure treatment. This is because of biochar effect to increase $\mathrm{pH}$ and retained water better than just manure.

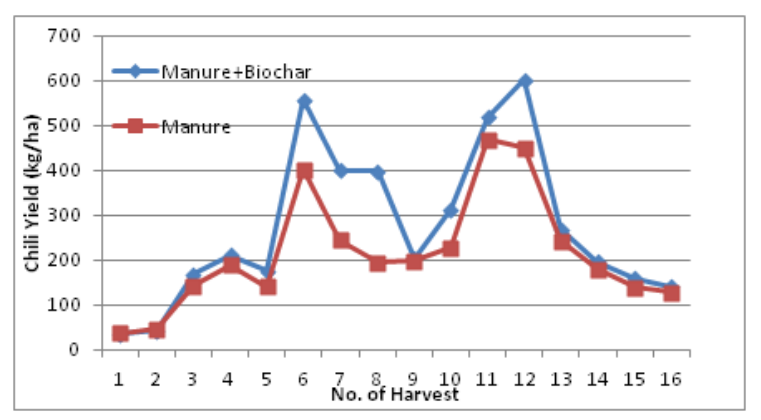

Figure1. The average of actual attained yield of chili by type of ameliorant from 16 consecutive harvest

Figure 2 showed comparison of attained fresh chili yield by type of fertilizer among conventional NPK, commercial AB-mix and AARD AB-mix in manure ameliorant and mixture of manure+biochar ameliorant respectively. In both of left and right figure showed that conventional NPK fertilizer attain much lower chili yield compared to commercial AB-mix and AARD's AB-mix. This is because of AB-mix fertilizer supplied complete macro and micro nutrient continuely, meanwhile convetional NPK just supplied nitrogen $(\mathrm{N})$, phosphorus $(\mathrm{P})$, and potassium $(\mathrm{K})$ nutrient discontinuely.
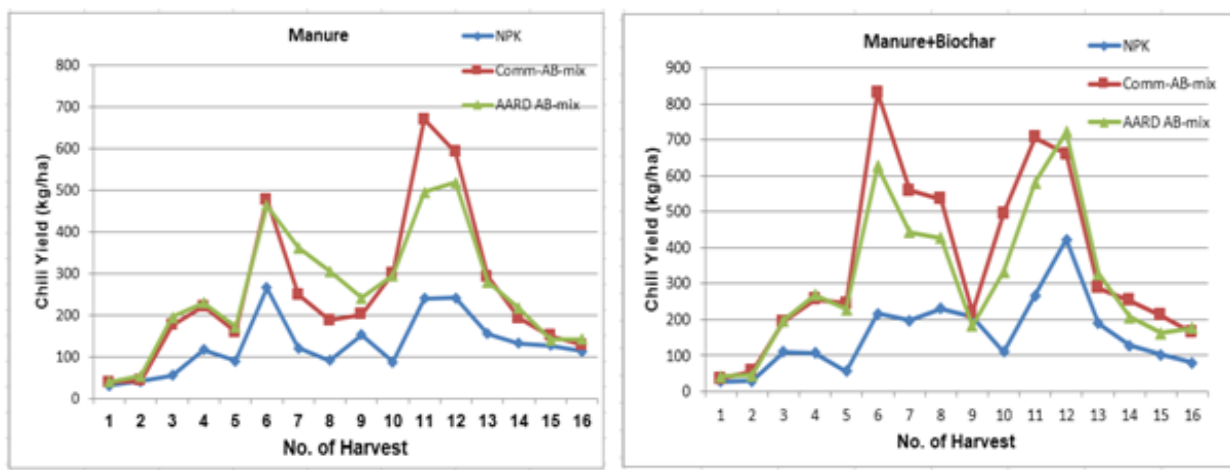

Figure2. The average of actual attained fresh chili yield by type of fertilizers from 16 consecutive harvest 
Potential attained yield should be higher if there is no bad weather during harvesting season. Heavy rain during $7^{\text {th }}$ to $10^{\text {th }}$ harvest decreased chili yield drastically due to fungi infestation which caused most of chili fruit experienced root and fall before mature (Figure 1 and Figure 2). Normally, crop yield of chili should be follow sigmoid curve pattern. If the $7^{\text {th }}$ to $10^{\text {th }}$ harvest are consider as missing data, therefore yield curve of chili could be developed. Both of manure and manure+biochar yield curve forming sigmoid pattern and the peak of chili yield should be reached at $9^{\text {th }}$ to $10^{\text {th }}$ harvests (Figure 3). But, because of bad weather, crop yield decreased sharply during 5 consecutive harvest. Base on potential attained yield curve, predicted potential loss of yield is about $23-41 \%$ on manure treatment and $17-31 \%$ on manure+biochar treatment. This indicate that plant treated with manure+biochar ameliorant is more tolerant to bad weather compare to just manure ameliorant.
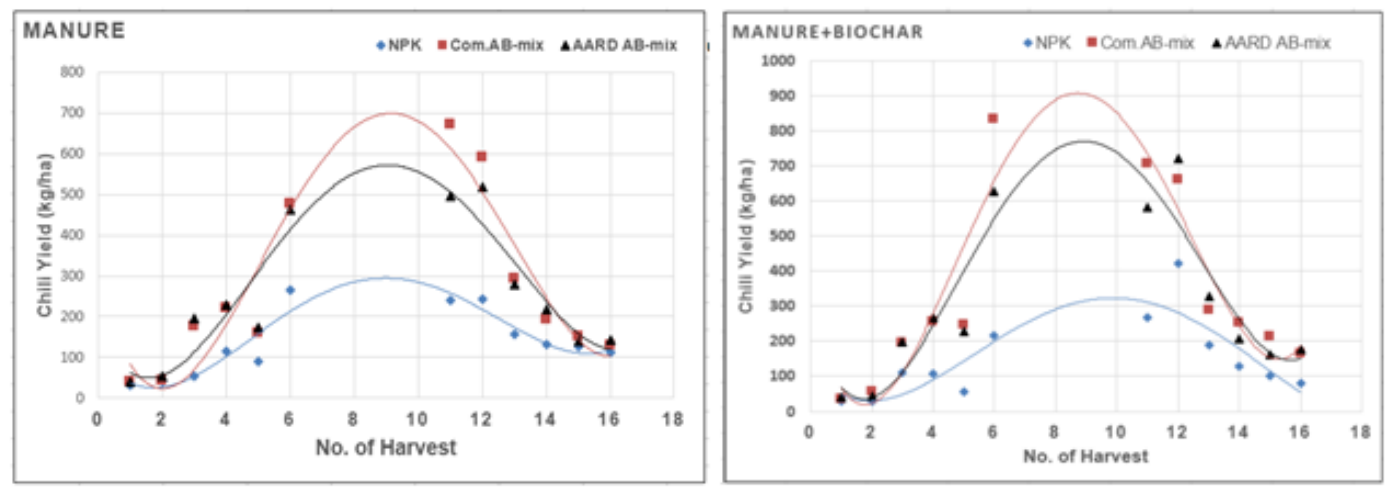

Figure3. The average of potential attained yieldof chili by type of fertilizer from 16 consecutive harvest

\subsection{Financial Feasibility}

The cost structure of chili cultivation consist of fixed cost, input cost, labor cost and other cost. Fixed cost consist ofpurchasing tools, apparatus and installing irrigation network that can be applied within 6-8 cropping seasons. Economic analysis of chili cultivation using farmer practices and using fertigation system showed in Table 7 . Chili cultivation using fertigation system needs expensive fertigation tool set, however it can be used for 6-8 planting seasons, so that cost for that equipment can be distributed for 6-8 season. Chili cultivation using conventional farming which is commonly practiced by farmerthat need less inputs cost, but higher labor cost compared to fertigation system.In conventional method, kind of fertilizer need is solid NPK compound fertilizer. Meanwhile fertigation system need $\mathrm{AB}$-mix formula fertilizer that containing of complete macro and micro nutrients. That is why chili cultivation using fertigation methods causes better plant growth performance compare to conventional chilli cultivation practices.

Total cost needs in conventional methods is about USD 5,683/ha/season much lower than fertigation method with total cost about USD 7,641/ha/season. Fresh chili yield obtained with using conventional methods was about $2,584 \mathrm{~kg} / \mathrm{ha}$, meanwhile chili yield obtained with using fertigation methods was about $5.711 \mathrm{~kg} / \mathrm{ha}$. That's mean production cost of each $\mathrm{kg}$ chili using conventional methods was about USD 2.29/kg, whereas if chili cultivation using fertigation methods, production cost was about USD 1.34/kg. Nett benefit attained chili cultivation using fertigation methods much higher (USD 6,636/ha) compared to conventional methods at about USD 777/ha. This is in line with similar studies in Malaysia, where the costs of production for chili using fertigation systems under rain shelter much lower or at about RM 1.19/kg compared to RM 2.03/kg using the conventional method (Mods et al. 2016). The net income per season per hectare for planting chilli using the fertigation system under rain shelter was RM 105,654 and open fertigation was RM 77,415, which were higher than the conventional method (RM55,900). Chili cultivation using the fertigation method had been proven to increase the yield and income of farmers and entrepreneurs compared to the conventional method. The high cost or initial capital will be offset by the higher production.

Analysis of financial feasibility output showed that introduced fertigation based cihili production technology was financially feasible. Indicators of feasibility analysis such as R/C, B/C Ratio and marginal benefit cost ratio (MBCR) were 1.87; 0.87; and 4.12. For example every USD 1.0 aditional cost will give USD 1.87 gross return and about USD 0.87 net benefit respectively. On the other hand, by comparing the introduced production technology with conventional farming technology or farmers' 
Effect of Fertilizers Application through Fertigation System on Chili Cultivation on Tin Mined Land in Bangka Island

practices in chilli production system, the MBCR indicator showed that every USD 1.0 will give additional benefit about USD 4.12. So that the introduced chilli production system was able to increase farmers' on-farm income significantly.

Table9. Output of financial feasibility analysis between conventional practices and introduces fertigation system.

\begin{tabular}{|c|c|c|c|c|c|c|}
\hline \multirow[b]{2}{*}{ Item } & \multicolumn{3}{|c|}{ Farmer's Practices } & \multicolumn{3}{|c|}{ Fertigation System } \\
\hline & $\underset{n t}{A m o u}$ & $\begin{array}{l}\text { Unit Price } \\
\text { (USD/unit } \\
\quad \text { ) }\end{array}$ & $\begin{array}{l}\text { Value } \\
\text { (USD) }\end{array}$ & $\underset{t}{\text { Amoun }}$ & $\begin{array}{c}\text { Unit } \\
\text { Price } \\
\text { (USD/un } \\
\text { it) }\end{array}$ & Cost (USD) \\
\hline $\begin{array}{l}\text { Fix Cost: Fertigation set (material } \\
\text { and installing cost) that can be } \\
\text { used for 6-8 planting seasons } \\
\text { (USD 12,857) }\end{array}$ & & & & $\mathbf{1 2 , 8 5 7}$ & & 2,143 \\
\hline Manure (ton) & 24 & 35.71 & 857.04 & 24 & 35.71 & 857.04 \\
\hline Seeds (kg) & 40 & 1.43 & 57.20 & 40 & 1.43 & 57.20 \\
\hline Fertilizer $(\mathrm{kg})$ & 800 & 0.714 & 571.20 & 20 & 53.57 & $1,071.40$ \\
\hline Plastic mulch & 20 & 28.57 & 571.40 & 20 & 28.57 & 571.40 \\
\hline Insecticide and Fungicide (lt) & 10 & 35.71 & 357.10 & 10 & 35.71 & 357.10 \\
\hline Input Cost & & & $2,413.94$ & & & $2,914.14$ \\
\hline Nursery $(\mathrm{kg})$ & 60 & 5.71 & 342.60 & 60 & 5.71 & 342.60 \\
\hline $\begin{array}{c}\text { Land preparation and bed } \\
\text { development (MD) }\end{array}$ & 80 & 5.71 & 456.80 & 80 & 5.71 & 456.80 \\
\hline Transplanting (MD) & 40 & 5.71 & 228.40 & 40 & 5.71 & 228.40 \\
\hline Crop maintenance (MD) & 120 & 5.71 & 685.20 & 120 & 5.71 & 685.20 \\
\hline Labor for watering (MD) & 120 & 5.71 & 685.20 & 20 & 5.71 & 114.20 \\
\hline Fertilizing $(\mathrm{MD})$ & 30 & 5.71 & 171.30 & 10 & 5.71 & 57.10 \\
\hline Harvesting (MD) & 60 & 5.71 & 342.60 & 60 & 5.71 & 342.60 \\
\hline Labor Cost & & & $2,912.10$ & & & $2,226.90$ \\
\hline Other cost & & & 357.14 & & & 357.14 \\
\hline Total Cost & & & $5,683.18$ & & & $7,641.18$ \\
\hline Average Chili Yield (kg) & 2,584 & & & 5,711 & & \\
\hline Total Return & 2,584 & 2.50 & $6,460.00$ & 5,711 & 2.50 & $14,277.50$ \\
\hline Benefit & & & 776.82 & & & $6,636.32$ \\
\hline $\mathrm{B} / \mathrm{C}$ ratio & & & 0.14 & & & 0.87 \\
\hline $\mathrm{R} / \mathrm{C}$ ratio & & & 1.14 & & & 1.87 \\
\hline MBCR & & & & & & 2.99 \\
\hline
\end{tabular}

\section{CONCLUSION}

Tin mined land dominated by sandy tailing with $84 \%$ sand fraction, characterized by low CEC and low organic content and nutrient status. Fertilizers applied potentially prone to leaching due to low nutrient holding capacity and high fast drainage pores. The application of manure+biochar as soil amendment showed better plant growth compared to just manure ameliorant. The mixture of manure+biochar was also increased total number of harvested chili and total chili yield from 16 consecutive harvesting. It was because of bio-char has higher $\mathrm{pH}$ compare to manure. Fertilizers application through fertigation system can improve plant growth and significantly increased yield of chili on tin mined land. The increase of chili yield obtained through fertigation system maybe due to continuous availability of complete nutrient both of macro and micro nutrient. The commercial ABmix increased fresh chili yield about $130 \%$ compare to conventional NPK treatment. Meanwhile, the AARD developed AB-mix also increased fresh chili yield about twice (100\%) compare to conventional NPK. There is no significantly different between commercial AB-mix and AARD developed $\mathrm{AB}$-mix. It was revealed that the effectiveness of both of AB-mix formula is almost same.

Financially, the introduced fertigation based chili production technology was highly financially feasible compared with conventional farming or farmer's practices. For example the marginal benefit accepted as an impact of this fertigation technology in chilli farming could give more then 4 times additional on-farm income to farmers. 


\section{ACKNOWLEDGEMENT}

The authors wish to acknowledge the Indonesian Agency for Agricultural Research and Development who financing this research activities. Many thanks also addresses to our colleagues and field staffs for their assistance.

\section{REFERENCES}

[1] A'fifah AR., M.R. Ismail, E.M.W. Puteri, S.N.A. Abdullah, Z. Berahim, R. Bakhtiar and H. Kausar. 2015. Optimum Fertigation Requirement and Crop Coefficients of Chilli (Capsicum annuиm) Grown in Soilless Medium in the Tropic Climate. Int. J. Agric. Biol., 17: 80-88

[2] Anonim, 2018. Biochar. https://en.wikipedia.org/wiki/Biochar

[3] Asmarhansyah, D. Rusmawan, and Muzammil. 2012. Soil chemistry and yield of maize as influenced by different levels of fertilizer in ex-tin land Central Bangka, Kepulauan Bangka Belitung. International Maize Conference Agribusiness of Maize- Livestock Integration. Gorotalo, 21 - 23 November 2012. Pp $205-208$.

[4] Ang LH. 1994. Problems and prospects of forestation on sandy tin tailings in Peninsular Malaysia. J. of Tropical Forest Science 7(1):87-105.

[5] Ang L.H., Seel WE. and Mullins C. 1999. Microclimate and water status of sand tailing at an-ex-mining site in Peninsular Malaysia. J. of Tropical Forest Science 11(1):157-170.

[6] Awang K. 1988. Tin tailings and their possible reclamation in Malaysia in Adisoemanto, S. (ed.). 1988. in Regional Workshop on Eco-development Process for degraded land resources in Southeast Asia, Bogor 23-25 August 1988.

[7] Bangka Agency for Development Planning (Bappeda). 2000. Profile of Bangka Investation. Bappeda Bangka, Sungailiat.

[8] Bappeda Provinsi Kepulauan Bangka Belitung. 2007. Kondisi kerusakan lingkungan hidup di Provinsi Kepulauan Bangka Belitung. Bahan Presentasi Bapedalda Provinsi Kepulauan Bangka Belitung, Pangkalpinang.

[9] Chantai S. And S. Wonprasaid. 2016. Effects of Fertigation and Water Application Frequency on Yield, Water and Fertilizer Use Efficiency of Chili (Capsicum annuum L.).Int'l Journal of Research in Chemical, Metallurgical and Civil Engg. (IJRCMCE) 3 (2): 209-213

[10] Hanura 2005. Perbaikan sifat kimia bahan tailing asal lahan pasca penambangan timah yang diberi kompos dan pengaruhnya terhadap pertumbuhan tanaman kedelai. Tesis. Program Studi llmu Tanaman Program Pascasarjana Universitas Sriwijaya (tidak dipublikasikan).

[11] Latifah 2000. Keragaman Pertumbuhan Acacia mangium Wild pada lahan bekas tambang timah (studi kasus di area kerja PT. Tambang Timah). Tesis Magister Ilmu Kehutanan Program Pascasarjana IPB, Bogor (tidak dipublikasikan)

[12] Latifah 2003. Kegiatan Reklamasi Lahan Pada Bekas Tambang. http://library.usu.ac.id/download/fp/hutansiti1.pdf [8 april 2015].

[13] Marimin, H.S. 2014. Agent Based Modelling for Investment an Operational Risk Consideration in Palm Oil Supply Change. International of Supply Change Management 1(1): 30-40.

[14] Muhammad, L.A; Adeguna, A.H; Olatinwo, K.B; and Saadu, T.A. 2012. Economic Analysis of Floricultural Plant Production in Kwara State, North Central Negeria. Asian Journal of Agricultural and Rural Development: 2(3): 373-380.

[15] Mohd, Y.S., A. M. Arshad, NF.H. Muhamad, and N.J. Sidek. 2015. Potential and Viability of Chilli Cultivation Using Fertigation Technology in Malaysia. Int'l J. of Innovation and Applied Studies17 (4):1114-1119

[16] Nesthad, N., Kurien E.K., Mathew E.K. and A. Varughese. 2013. Impact of Fertigation and Drip System Layout on Performance of Chilli (Capsicum Annum). International Journal of Engineering Research and Development 7 (9):85-88

[17] Pusat Penelitian Bioteknologi Hutan dan Lingkungan IPB. 2002. Effect of bio-organic on soil and plant improvement of post tin mine site at PT. Koba Tin Project Area, Bangka. Pusat Penelitian Bioteknologi IPB, Bogor.

[18] Subardja, D., A. Kasno, Sutono dan H. Sosiawan. (2012). Identifikasi dan karakterisasi lahan bekas tambang timah untuk pencetakan sawahbaru di Perlang, Bangka Tengah. Prosiding Seminar Nasional Sumberdaya Lahan Pertanian. Bogor, 30 November - 1 Desember 2010. Hlm; 109 -122. 
[19] Santi R. 2005. Pertumbuhan Nilam (Pogostemoncablin Benth) pada sandy tailing asal lahan pasca penambangan timah yang diberi kompos dan tanah kupasan (overburden). Tesis. Program Studi Ilmu Tanaman Program Pascasarjana Universitas Sriwijaya (tidak dipublikasikan).

[20] Setiadi Y. 2006. The Revegetation Strategies for Rehabilitating Degraded Land after Mine Operation. www.mm.helsinki. (diakses tanggal 24 Npember 2007).

[21] Tanpibal, V. dan p. Sahunalu .1989. Characteristics and management of tin mine tailing in Thailand. Soil Technology 2:17-26.

Citation: IGM. Subiksa, et.al. "Effect of Fertilizers Application through Fertigation System on Chili Cultivation on Tin Mined Land in Bangka Island" International Journal of Research Studies in Agricultural Sciences (IJRSAS), 2019; 5(5), pp. 15-26, http://dx.doi.org/10.20431/2454-6224.0505003

Copyright: (C) 2019 Authors. This is an open-access article distributed under the terms of the Creative Commons Attribution License, which permits unrestricted use, distribution, and reproduction in any medium, provided the original author and source are credited. 